\title{
PENERAPAN MANAJEMEN SAINS TEKNIK PROGRAM LINIER DALAM DUNIA USAHA
}

\author{
Erniza Dwi Wahyuni \\ $185100042 P$ \\ Fakultas Komputer \\ ernizadwiwahyuni.student@umitra.ac.id
}

\begin{abstract}
Manajemen Sain merupakan pendekatan pengambilan keputusan manajerial yang didasarkan atas metode-metode ilmiah yang menggunakan banyak analisis kuantitatif. Sains manajemen adalah disiplin ilmu yag diakui dan diterima dalam bidang ilmu administrasi usaha. Penerapan teknik - teknik sains manajemen telah meluas, dan dianggap telah meningkatkan efisiensi dan produktifitas perusahaan. Tahap akhir dalam proses sains manajemen adalah untuk memecahkan masalah seperti pada implementasi. Implementasi merupakan pelaksanaan nyata dari model yang telah dikembangkan.
\end{abstract}

Seorang manajer dalam suatu perusahaan dalam mengambil keputusan memerluka usaha atau cara yang maksimal dan seefisien mungkin, namun dalam mencapai tujuan tersebut terdapat banyak kendala atau batasan yang terjadi. Misalnya untuk mencapai target produksi dan penjualan, akan ditemukan beberapa kendala, misalnya bahan baku yang kurang mencukupi, biaya produksi meningkat sesuai inflasi, SDM yang belum kompeten.

Secara umum tujuan perusahaan yang paling sering adalah mencapai laba untuk keuntungan maksimum dan dengan biaya yang seminim mungkin. Saat manajer berusaha untuk menyelesaikan masalah dengan mencari tujuan yang dibatasi ini, maka Program Linier menjadi salah satu acuan yang sering digunakan.

Kata Kunci : Program Linier. 
A. PENDAHULUAN

Manajemen Sains merupakan pendekatan pengambilan keputusan manajerial yang didasarkan atas metode-metode ilmiah yang menggunakan banyak analisis kuantitatif. Berbagai nama diberikan untuk bidang ilmu yang melibatkan pendekatan-pendekatan

kuantitatif untuk pengambilan keputusan selain manajemen sains, nama lainnya yang dikenal dan diterima secara luas adalah Riset Operasi (Operation Research). Sekarang banyak yang menggunakan istirah riset operasi dan manajemen sains secara bergantian dalam pengertian yang sama.

Revolusi manajemen sains pada awal 1900an, yang dicetuskan oleh Frederic W. Taylor, memberikan dasar bagi manajemen sains dan operasi riset. Namun manajemen sains/riset operasi modern umumnya dianggap muncul selama periode Perang Dunia II, ketika tim riset operasi dibentuk untuk menangani masalah-masalah stategis dan taktis yang dihadapi militer. Tim ini, yang sering kali terdiri atas orang-orang dari bebagai bidang ilmu (misalnya ahli matematika, teknik, dan perilaku), bersama sama memecahkan masalah dengan menggunakan metode ilmiah. Setelah perang selesai, banyak anggota tim ini melanjutkan riset dengan pendekatan kuantitatif untuk pengambilan keputusan.

\section{B. PEMBAHASAN / STUDI KASUS}

Banyak keputusan utama yang dihadapi oleh seorang manajer perusahaan untuk tujuan perusahaan dengan batasan situasi lingkungan operasi. Pembatasan meliputi sumber daya, misalnya waktu, tenaga kerja, energi, bahan baku, berupa bentuk batasan pedoman misalnya resep untuk membuat, spesifikasi teknik. Secara umum tujuan perusahaan yang paling serig sedapat mungkin memaksimalkan laba. Tujuan dari unit organisasi lain yang lain dari suatu organisasi biasanya beupa meminimalkan biaya. Saat manajer selesaikan masalah dengan mencapai tujuan yang dibatasi oleh batasan isi manajemen berupa program linier sering digunakan dalam penggunaan teknik program linier.

Pertama, masalah harus disikan sebagai sesuatu yang dapat diselesaikan dengan Program Linier, luang tidak terstruktur harus dapat dirumuskan dalam model matematika:struktur. Ketiga model harus diselesaikan dengan teknik matematika teknik program linier mengembahkan bahwa hubungan fungsi linier dalam model matematika adalah linier dan teknik pemecahan masalah terdiri dari langkah-langkah 
matematika yang telah ditetapkan disebut program.

Tahap dalam penggunaan teknik Program Linier Pertama masalah harus dapat diidentifikasi sebagai suatu yang dapat diselesaikan dengan program Linier. Kedua masalah yang tidak terstruktur harus dapat diselesaikan dalam model matematika sehingga menjadi terstruktur. Ketiga model harus diselesaikan dengan teknik matematika yang telah dibuat.

C. ID SECURITY

QWTD4452377-ASP-5244107

\section{KESIMPULAN}

Sains manajemen adalah penerapan ilmiah yang menggunakan pendekatan ilmiah untuk memecahkan masalah manajemen dalam rangka membantu manajer untuk mengambil keputusan yang baik. Tujuan utama dari manajemen sains adalah untuk menyeelesaikan masalahmasalah yang dihadapi oleh seorang manajer baik yang bergerak dalam sektor publik maupun swasta dalam proses pengambilan keputusan degan cara pendekatan model-model matematika.Tujuan perusahaan yang paling sering adalah mencapai laba atau keuntungan maksimum dan dengan biaya yang seminimum mungkin. Model program Linier terdiri dari komponen dan karakteristik tertentu.Komponen model termasuk variabel keputusan, fungsi tujuan, dan batasan model.

Terdapat 3 tahap dalam menggunakan Teknik Program Linier, pertama masalah harus dapat diidentifikasi sebagai sesuatu yang dapat diselrsaikan dengan program linier, kedua masalah yang tidak terstruktur harus dapat diselesaikan dalam model matematika.

\section{E. DISKUSI}

Saya bersama teman saya bernama Apriyan Ariatama mendiskusikan tentang contoh ini dengan sangat baik Hasil diskusi dari materi ini adalah Penerapan teknik - teknik sains manajemen telah meluas, dan dianggap telah meningkatkan efisiensi dan produktifitas perusahaan. Tahap akhir dalam proses sains manajemen adalah untuk memecahkan masalah seperti pada implementasi.

Secara umum tujuan perusahaan yang paling sering adalah mencapai laba untuk keuntungan maksimum dan dengan biaya yang seminim mungkin. Saat manajer berusaha untuk menyelesaikan masalah dengan mencari tujuan yang dibatasi ini, maka Program Linier menjadi salah satu acuan yang sering digunakan

\section{F. REFERENCE}

[1] O. M. Febriani and A. S. Putra, "Sistem Informasi Monitoring Inventori Barang Pada Balai 
Riset Standardisasi Industri Bandar Lampung," J. Inform., vol. 13, no. 1, pp. 90-98, 2014.

[2] A. S. Putra, "Paperplain: Execution Fundamental Create Application With Borland Delphi 7.0 University Of Mitra Indonesia," 2018.

[3] A. S. Putra, "2018 Artikel Struktur Data, Audit Dan Jaringan Komputer," 2018.

[4] A. S. Putra, "ALIAS MANAGER USED IN STUDI CASE DB DEMOS."

[5] A. S. Putra, "COMPREHENSIVE SET OF PROFESSIONAL FOR DISTRIBUTE COMPUTING."

[6] A. S. Putra, "DATA ORIENTED RECOGNITION IN BORLAND DELPHI 7.0."

[7] A. S. Putra, "EMBARCADERO DELPHI XE 2 IN GPUPOWERED FIREMONKEY APPLICATION."

[8] A. S. Putra, "HAK ATAS KEKAYAAN INTELEKTUAL DALAM DUNIA TEKNOLOGY BERBASIS REVOLUSI INDUSTRI 4.0."

[9] A. S. Putra, "IMPLEMENTASI PERATURAN

PERUNDANGAN UU. NO 31 TAHUN 2000 TENTANG DESAIN INDUSTRI BERBASIS INFORMATION TECHNOLOGY."

[10] A. S. Putra, "IMPLEMENTATION OF PARADOX DBASE."

[11] A. S. Putra, "IMPLEMENTATION OF TRADE SECRET CASE STUDY SAMSUNG MOBILE

PHONE."

[12]

A.

"IMPLEMENTATION

PATENT FOR APPLICATION WEB BASED CASE STUDI WWW. PUBLIKLAMPUNG. COM."

[13] A "IMPLEMENTATION SYSTEM FIRST TO INVENT IN DIGIT ALLY INDUSTRY."

[14] A. S. Putra, "MANUAL REPORT \& INTEGRATED DEVELOPMENT ENVIRONMENT BORLAND DELPHI 7.0."

[15] A. S. Putra, "PATENT AS RELEVAN SUPPORT RESEARCH."

[16] A. S. Putra, "PATENT FOR RESEARCH STUDY CASE OF APPLE. Inc."

[17] A. S. Putra, "PATENT PROTECTION FOR APPLICATION INVENT."

[18] A. S. Putra, "QUICK REPORT IN PROPERTY PROGRAMMING."

[19] A. S. Putra, "REVIEW CIRCUIT LAYOUT COMPONENT REQUIREMENT ON ASUS NOTEBOOK."

[20] A. S. Putra, "REVIEW TRADEMARK PATENT FOR INDUSTRIAL TECHNOLOGY BASED 4.0."

[21] A. S. Putra, "TOOLBAR COMPONENT PALLETTE IN OBJECT ORIENTED PROGRAMMING."

[22] A. S. Putra, "WORKING DIRECTORY SET FOR PARADOX 7."

[23] A. S. Putra, "ZQUERY 
CONNECTION

IMPLEMENTED

PROGRAMMING STUDI

CASE PT. BANK BCA Tbk."

[24] A. S. Putra, D. R. Aryanti, and I. Hartati, "Metode SAW (Simple Additive Weighting) sebagai Sistem Pendukung Keputusan Guru Berprestasi (Studi Kasus: SMK Global Surya)," in Prosiding Seminar Nasional Darmajaya, 2018, vol. 1, no. 1, pp. 85-97.

[25] A. S. Putra and O. M. Febriani, "Knowledge Management Online Application in PDAM Lampung Province," in Prosiding International conference on Information Technology and Business (ICITB), 2018, pp. 181-187.

[26] A. S. Putra, O. M. Febriani, and B. Bachry, "Implementasi Genetic Fuzzy System Untuk Mengidentifikasi Hasil Curian Kendaraan Bermotor Di Polda Lampung," SIMADA (Jurnal Sist. Inf. dan Manaj. Basis Data), vol. 1, no. 1, pp. 21-30, 2018.

[27] A. S. Putra, H. Sukri, and K. Zuhri, "Sistem Monitoring Realtime Jaringan Irigasi Desa (JIDES) Dengan Konsep Jaringan Sensor Nirkabel," IJEIS (Indonesian J. Electron. Instrum. Syst., vol. 8, no. 2, pp. 221-232.

[28] D. P. Sari, O. M. Febriani, and A. S. Putra, "Perancangan Sistem Informasi SDM Berprestasi pada SD Global Surya," in Prosiding Seminar Nasional Darmajaya, 2018, vol. 1, no. 1, pp. 289-294. 